\title{
Flexural Strengthening of Reinforced Concrete Beams with Externally Bonded Hybrid FRP Laminate
}

\author{
K. Pradeeba, A.Rajasekaran
}

\begin{abstract}
This paper enumerates the effectiveness of externally bonded Hybrid Fiber Reinforced Polymers (HyFRP) laminates on reinforced concrete beams for flexural strengthening. A total of 5 reinforced concrete beams of size $150 \times 250$ in cross section and length of $3000 \mathrm{~mm}$ were considered in this study. All the beams were tested in four-point bending over a simple span of $2800 \mathrm{~mm}$. Of the above five beams, one beam served as reference beam and the other four beams were HyFRP laminated. The variables considered in this study included thickness of HyFRP laminate and composite ratio. Adequate measurement was acquired on load and deflection characteristic of HyFRP strengthened as well as reference beam.
\end{abstract}

Keywords: Basalt, Ductility, Glass, HyFRP, laminate

\section{INTRODUCTION}

A variety of reinforced concrete structures such as residential as well as commercial buildings and highway bridges which were build more than 40 years ago might be subjected to structural damage due to disasters such as earthquakes, any other accidents, or degradation due to time were demolished without considering the possibility for strengthening or restoring the capacity of the structure. The most critical issues civil engineering field is strengthening of structural members. Early worsening of structures resulted in exploration of new pioneering techniques of strengthening. The selection of strengthening technique would augment the serviceability of the structure. Strengthening of structures would accomplished with some restrictions like building operations, mobility, financial plan etc. The report of American Concrete Institute (ACI) 440 (2002), furnish the guiding principle to utilize the fibre reinforced polymer in both external and internal application as reinforcement. ACI 440.1R report incorporate the guidelines for using FRP as internal reinforcement and ACI 440.2R report incorporate the guidelines for using for FRP as external reinforcement. For all the structural members under flexure, shear, axial tension and compression members the guiding principle was incorporated in the report.

Manuscript received on August 29, 2021.

Revised Manuscript received on September 06, 2021.

Manuscript published on September 30, 2021.

*Correspondence Author

K. Pradeeba*, Research Scholar Department of Civil and Structural Engineering, Annamalai University, Annamalai Nagar, (Tamil Nadu), India. E-Mail: 1pradeebaphd1@gmail.com

Dr. A. Rajasekaran, Professor Department of Civil and Structural Engineering, Annamalai University, Annamalai Nagar, (Tamil Nadu), India.

(C) The Authors. Published by Blue Eyes Intelligence Engineering and Sciences Publication (BEIESP). This is an open access article under the CC BY-NC-ND license (http://creativecommons.org/licenses/by-nc-nd/4.0/)
The present study has been undertaken to assess the flexural characteristics of externally bonded Hybrid Fibre Reinforced Polymer (HyFRP) laminates in Reinforced Concrete (RC) beams. The spotlight is on the load and deflection characteristics of HyFRP laminated RC beams. Assessment was done connecting the un-strengthened and strengthened beams and appropriate conclusions are drawn based on the results of the investigation carried out.

Kim and Shin (2011) examined the effectiveness of hybrid FRPs on flexural performance of RC beams. Different arrangements of carbon and glass fibre sheets of the hybrid FRPs showed control on enhancement of flexural strengthening RC beams. A total of 14 reinforced concrete beams were cast, strengthened with hybrid FRP and tested under four-point bending. Different configurations of CFRP and GFRP sheets were utilized. The beams under loaded condition, retrofit was carried out with two or three layers of hybrid FRPs and then the load increased until failure. The study concludes that hybrid FRP enhanced the ultimate load, deflection ductility and stiffness of RC beams with respect to orders of FRP layers. Attariet al., (2012) examined the adeptness of hybrid fibre reinforced polymer (Glass-Carbon) structure in external bonding to strengthen the reinforced concrete beams. Dissimilar strengthening configurations were adapted for seven beams. The study parameters such as ultimate load, deflection, stiffness, deflection ductility and mode of failure are discussed for all the test specimens. The proposed a model to predict the study parameters of strengthened beams. The model results showed good agreement with those of test results. The authors reported that the twin layer glass-carbon FRP fabric as a strengthening configuration for reinforced concrete structural element. Hawileh et al.,(2014) examined the flexural performance of RC beams with dissimilar combinations of externally bonded Glass and Carbon Fiber Reinforced Polymer as hybrid FRP laminate. One reference beam and four strengthened beams with glass, carbon and hybrid FRP laminates at the bottom tension zone of beam was utilized. All the beams were tested under four-point bending to examine the efficiency of hybrid FRP laminates on flexural strengthening. The necessary data were recorded and test results concluded that the strengthened beams exhibitan increase in ultimate load carrying capacity up to $98 \%$ when compared with reference beam. The load carrying capacity of the tested specimens was then predicted by the As per ACI 440.2R-08 guidelines the ultimate load carrying capacity of the strengthened beam was predicted and it shows good agreement with those of experimental results. Esmaeel (2015) studied the performance of RC beams strengthened with Hybrid Composite Plate (HCP).

Published By:

Blue Eyes Intelligence Engineering and Sciences Publication (BEIESP)

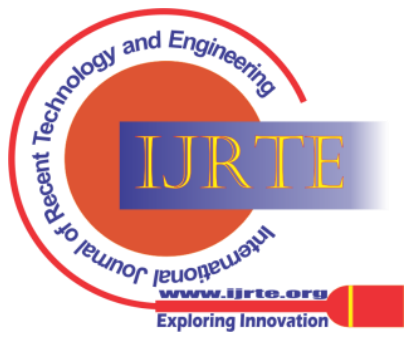


The study emphasis on evaluation of characteristics of HCP strengthened reinforced concrete beams subjected to flexure. HCP assures elevated durability to strengthened elements and higher protection to FRP components. It delays the detachment of concrete substrate. A staggered configuration cover. The staggered layout of anchors exhibits an enhanced strength and ductility. The experimental results reported that the ultimate load of strengthened beams exhibit an increase of $167 \%$ with acceptable deflection ductility of around 4.0. Petrucci

et al.,(2015) examined the impact and flexural post-impact performance of ternary hybrid combination based on epoxy resin reinforced with fibres such as Glass- G, Basalt -B, Flax -F and Hemp - H in textile type, specifically FHB, GHB and GFB, has been explored. The impact and flexural post-impact behavior of ternary hybrid composites based on epoxy resin reinforced with different types of fibres, basalt (B), flax (F), hemp $(\mathrm{H})$ and glass $(\mathrm{G})$ in textile form, namely FHB, GHB and GFB, has been investigated.A clear hierarchy in terms of flexural performance is apparent, that is GFB > FHB > GHB: the test results reported that adding glass fiber would offer better result in existence of flax fibres but not in existence of hemp fibres. Sundar et al., (2016) studied the flexural performance of RC beams with combination of glass and carbon fibre reinforced polymer. The test results concluded that increase in percentage of glass fibre in hybrid fibre reinforced polymer increases the ultimate load carrying capacity. The HY14 designated beam show signs of utmost increase in ultimate load of $188 \%$ with respect to referencebeam. The HY14 beam exhibit a maximum decrease in deflection at ultimate load level was $68 \%$ with respect to reference beam.

\section{EXPERIMENTAL PLAN}

The experimental study comprises five beams of size $150 \times 250 \times 3000 \mathrm{~mm}$. The percentage steel ratio was $0.603 \%$ for all test beams. The beams were subjected to two-point loading in a loading frame of $500 \mathrm{kN}$ capacity. One beam served as reference beam without any strengthening and the other four beams were strengthened using HyFRP laminate. The thickness of HyFRP laminate and composite ratio varied for every test beams. The measurement on load at various levels, deflection at various load levels and character of failure of strengthened as well as the reference beam. The beam section is presented in Fig.1.

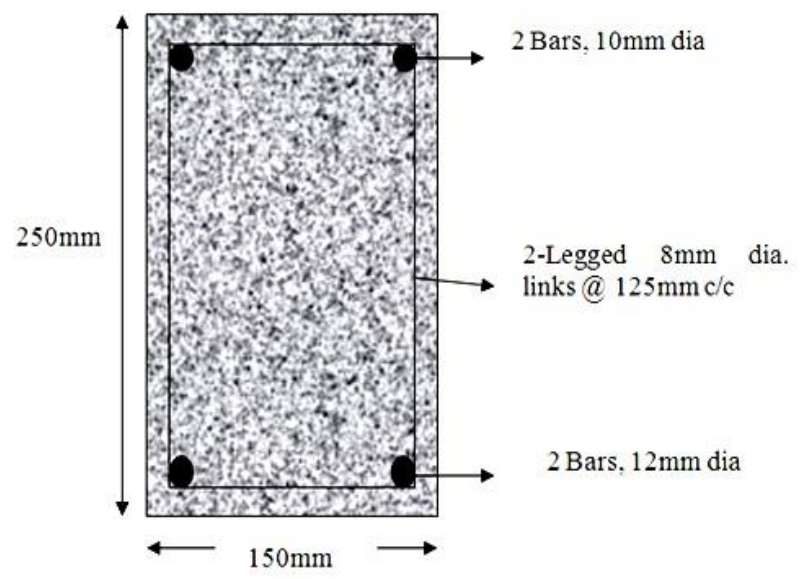

Fig. 1 Beam Section of anchors delayed the progress of detachment in concrete

The details of test beams are presented in Table 1. Four combinations of HyFRP laminates were used in this study, specifically, $90 \%$ Glass fibre $+10 \%$ Basalt fibre of thickness, $80 \%$ Glass fibre $+20 \%$ Basalt fibre, $70 \%$ Glass fibre $+30 \%$ Basalt fibre, $60 \%$ Glass fibre $+40 \%$ Basalt fibre, and 2.78 , $3.24,3.86$ and $4.24 \mathrm{~mm}$ respectively. The properties of HyFRP used in this study are given in Table 2.

Table 1 Detail of Test Specimens

\begin{tabular}{|c|c|c|c|c|c|c|}
\hline $\begin{array}{l}\dot{z} \\
\dot{\omega}\end{array}$ & 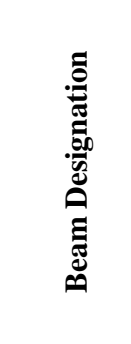 & 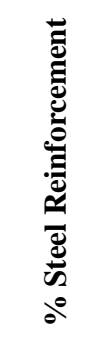 & 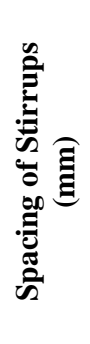 & 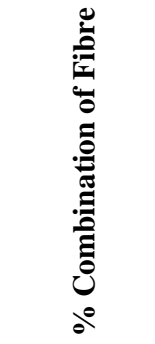 & 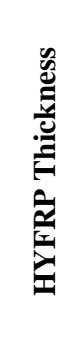 & 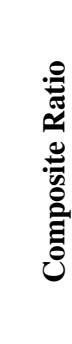 \\
\hline 1. & RB1 & 0.603 & 150 & 0 & 0 & 0 \\
\hline 2. & 1HyGB1 & 0.603 & 150 & $\begin{array}{l}\text { 90\%Glass } \\
10 \% \text { Basalt }\end{array}$ & 2.78 & 1.84 \\
\hline 3. & 1HyGB2 & 0.603 & 150 & $\begin{array}{l}\text { 80\%Glass } \\
20 \% \text { Basalt }\end{array}$ & 3.24 & 2.15 \\
\hline 4. & 1HyGB3 & 0.603 & 150 & $\begin{array}{l}\text { 70\%Glass } \\
\text { 30\%Basalt }\end{array}$ & 3.86 & 2.56 \\
\hline 5. & 1HyGB4 & 0.603 & 150 & $\begin{array}{l}60 \% \text { Glass } \\
40 \% \text { Basalt }\end{array}$ & 4.24 & 2.81 \\
\hline
\end{tabular}

Table 2 Laminated HyFRP Characteristics

\begin{tabular}{|c|c|c|c|c|}
\hline $\begin{array}{l}\text { Sl. } \\
\text { No. }\end{array}$ & $\begin{array}{c}\text { HyFRP } \\
\text { Category }\end{array}$ & $\begin{array}{l}\text { Thickness } \\
\text { in (mm) }\end{array}$ & $\begin{array}{c}\text { Tensile } \\
\text { Strength } \\
\text { (MPa) }\end{array}$ & $\begin{array}{c}\text { Elasticity } \\
\text { Modulus } \\
\text { (GPa) }\end{array}$ \\
\hline 1. & 1HyGB1 & 2.78 & 342.53 & 24.6 \\
\hline 2. & 1HyGB2 & 3.24 & 372.44 & 26.3 \\
\hline 3. & 1HyGB3 & 3.86 & 392.38 & 27.9 \\
\hline 4. & 1HyGB4 & 4.24 & 432.61 & 29.1 \\
\hline
\end{tabular}

\section{Preparation of Test Specimens}

The concrete ingredients were proportioned as per the mix design as per IS: 10262:2009 with the designed water-cement ratio. The beam specimens were cast using plywood moulds. Steel reinforcement cages as per design were arranged for each specimen. Necessary quantity of concrete was mixed in a motorized mixture machine. The interior portion of the moulds was applied with oil to avoid adhering of concrete with the mould.

Published By:

Blue Eyes Intelligence Engineering and Sciences Publication (BEIESP)

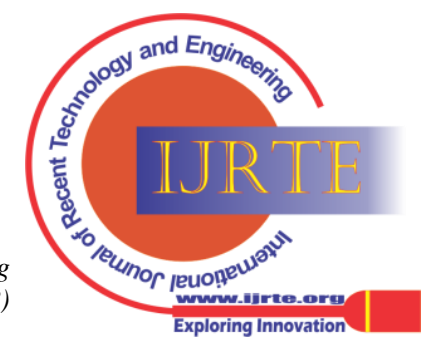


The concrete was poured in beam moulds with adequate compaction using needle vibrator to avoid honey comb. The beam specimens were de-moulded after 1day of casting and cured period was 28 days. The concrete substrates and HyFRP laminates were equipped well before bonding the laminates to the grained soffit of beams. Compressed air was blown over the soffit to before applying the adhesive compounds. Once the surface preparation completed, thoroughly mixed adhesive components were applied to the soffit of beam using a trowel. Adhesive thickness of $2 \mathrm{~mm}$ was kept up over the total length of test beam. The Hybrid FRP laminate was placed over the soffit of beam and then the dead weights kept over the laminate.

The process of test specimen preparation is presented in Figs. 2 to 11 .

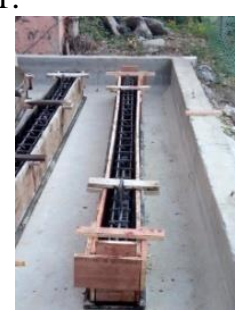

Fig. 2 Wooden Mould for Casting of Beams
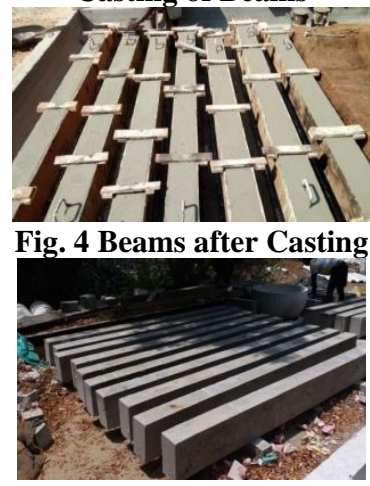

Fig. 6 De-moulded Specimen

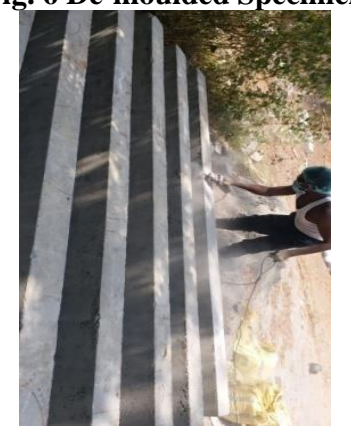

Fig. 8 Surface Preparation

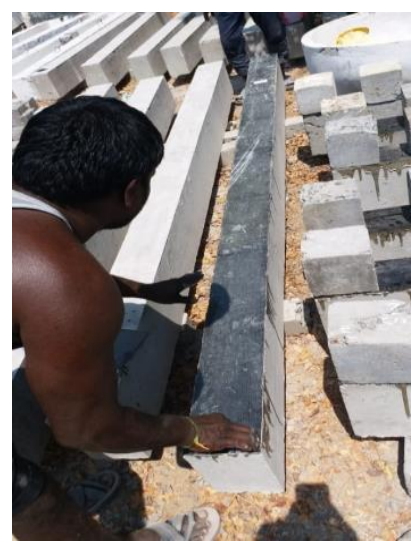

Fig. 10 Placement of HyFRP

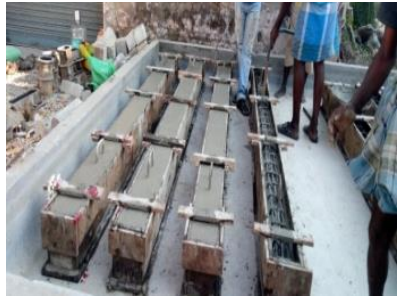

Fig. 3 Concrete being Placed and Compacted

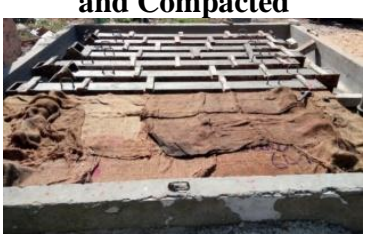

Fig. 5 Beams under Curing

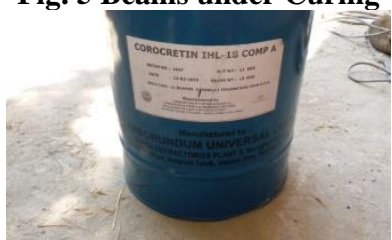

Fig. 7 Epoxy Resin used

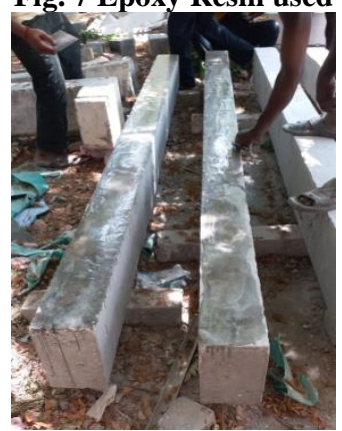

Fig. 9Application of Epoxy Resin

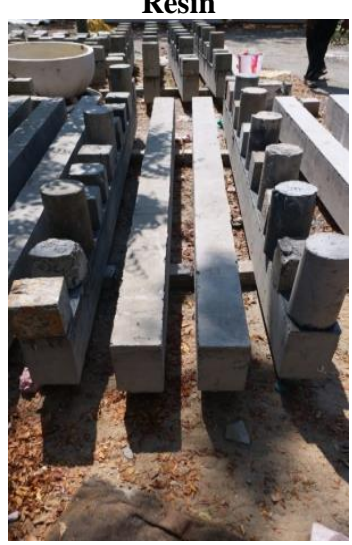

Fig. 11 Placing of Weight over the Laminate

\section{Test Procedure}

The beams strengthened with HyFRP and un-strengthened specimens subjected to 2 point loading in a loading frame capacity of $500 \mathrm{kN}$. The support condition of test beam was one end hinged and the other was roller support. The load was transferred through a spreader beam using a hydraulic jack. The load was measured through a proving ring. The dial gauges were used to measure the deflections at all load levels. To measure the deflection at the ultimate load level a designed mechanical gauge was used. The width of crack be measured and monitored using crack detection microscope. The propagation of crack was monitored at every load levels. The readings were recorded at all load levels until the test beam fails. The line sketch of experimental test set-up and actual test set-up with coupled instruments are made known through Fig. 12 and 13.

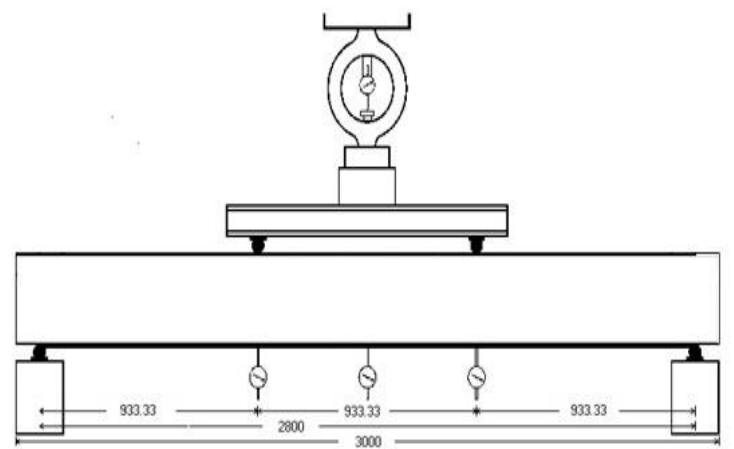

All dimensions are in ' $m m$ '

Fig. 12 Test Set-up

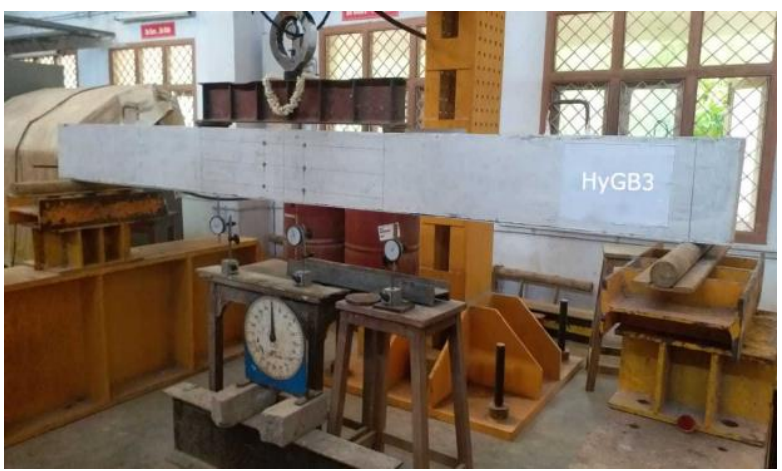

Fig. 13 Details of Instrumentation

\section{RESULTS AND DISCUSSION}

The study parameters such as first crack load, deflection with respect to first crack load, yield load, deflection by the side of yield load, service load, deflection by the side of service load, ultimate load, deflection by the side of ultimate load, deflection ductility, energy ductility, deflection ductility ratio, energy ductility ratio and energy absorption. The test results on the strength and deformation properties of the reference specimens and HyFRP laminated beams at dissimilar loading stages are accounted in Table 3 . The load versus deflection curve of the reference beam and HyFRP laminated beams are revealed in Fig. 14. The experimental results and load versus deflection graph indicate that RC beam laminated with $70 \%$ Glass + 30\%Basalt HyFRP laminate show signs of elevated load carrying capacity with enhanced ductility.

and Sciences Publication (BEIESP)

(C) Copyright: All rights reserved.

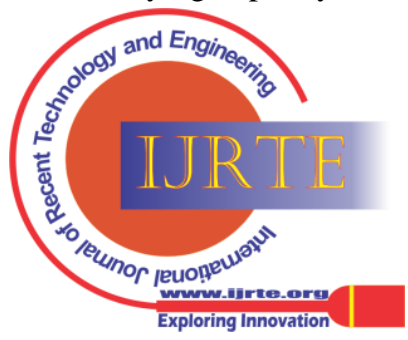




\section{Table 3 Test Results}

\begin{tabular}{|c|c|c|c|c|c|c|c|c|c|c|c|}
\hline 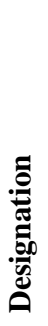 & 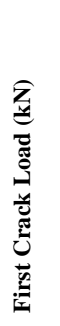 & 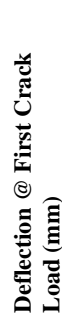 & 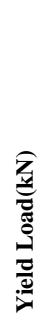 & 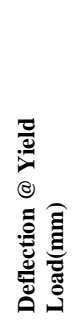 & 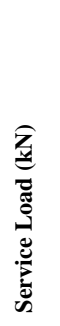 & 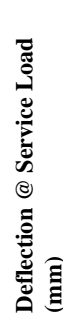 & 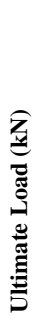 & 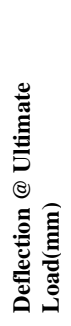 & 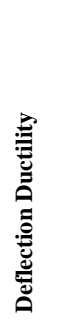 & 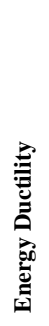 & 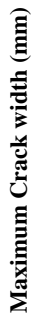 \\
\hline$\overline{\underline{z}}$ & $\begin{array}{l}\text { ô. } \\
\text { ฟิ }\end{array}$ & & $\begin{array}{l}\text { 웅 } \\
\text { ه }\end{array}$ & $\overrightarrow{\widehat{0}}$ & $\begin{array}{l}\text { o } \\
\dot{\varphi}\end{array}$ & $\begin{array}{l}\mathscr{O} \\
\ddot{\varphi}\end{array}$ & ت্ট் & $\begin{array}{l}\text { शे } \\
\dot{m}\end{array}$ & $\vec{F}$ & นึ & $\underset{-}{\widetilde{N}}$ \\
\hline 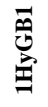 & $\begin{array}{l}\hat{\sigma} \\
\text { மे }\end{array}$ & $\begin{array}{l}\infty \\
\infty \\
\dot{m}\end{array}$ & $\begin{array}{l}\text { బ } \\
\text { กై }\end{array}$ & $\stackrel{100}{\rightarrow}$ & $\begin{array}{l}\text { రิ } \\
\text { مै }\end{array}$ & ஸे & $\begin{array}{l}\text { f̊ } \\
\text { ஜें }\end{array}$ & 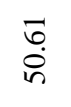 & $\stackrel{\overbrace{}}{\text { ஸ̣ }}$ & $\stackrel{\text { 뭄 }}{\sigma}$ & $\stackrel{\Xi}{\stackrel{\Xi}{ت}}$ \\
\hline 䛌 & $\begin{array}{l}\stackrel{⿰}{+} \\
\text { จे }\end{array}$ & $\overrightarrow{\widetilde{N}}$ & $\begin{array}{l}\text { ָे } \\
\vartheta\end{array}$ & $\begin{array}{l}0 \\
\stackrel{0}{0} \\
\infty\end{array}$ & $\begin{array}{l}\text { テे } \\
\text { ஓं }\end{array}$ & $\begin{array}{l}\bar{\sigma} \\
\vec{\exists}\end{array}$ & $\begin{array}{l}\underset{J}{J} \\
\stackrel{+}{0}\end{array}$ & $\begin{array}{l}\text { సి } \\
\text { ñ } \\
\text { ñ }\end{array}$ & 尺े & $\begin{array}{l}\mathscr{\infty} \\
\infty \\
\stackrel{0}{-1}\end{array}$ & $\begin{array}{l}\text { 。़ } \\
0\end{array}$ \\
\hline 芯 & $\begin{array}{l}\text { m. } \\
\text { mे }\end{array}$ & 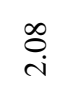 & $\begin{array}{l}\text { பे } \\
\text { |ूं }\end{array}$ & $\begin{array}{l}\curvearrowright \\
\infty \\
\infty\end{array}$ & $\begin{array}{l}\infty \\
\infty \\
\end{array}$ & $\begin{array}{l}\text { O̦ } \\
\text { ஸे }\end{array}$ & $\begin{array}{l}M \\
\infty \\
\dot{0} \\
\ddots 1\end{array}$ & 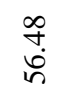 & $\begin{array}{l}\forall \\
\dot{6}\end{array}$ & $\stackrel{\infty}{\stackrel{\infty}{\xi}} \underset{-}{-}$ & $\begin{array}{l}\stackrel{\infty}{\infty} \\
0 \\
0\end{array}$ \\
\hline
\end{tabular}

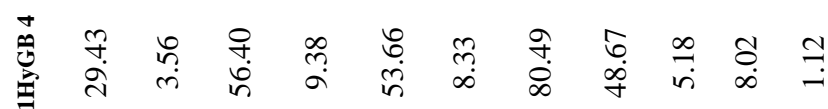

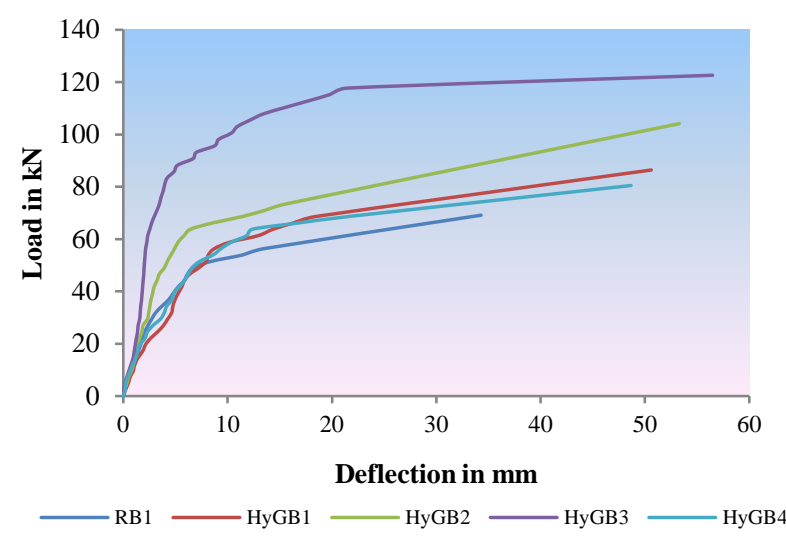

Fig. 14 Load - Deflection Responses of Test Beams

Fig. 14 inferred that the retort of load-deflection curve for the test beam specimen RB1 show signs of three zones of performance. In the first zone, stiffness of beam found to be elevated at the level of low loads representing the linear elastic behavior of concrete. In the next zone, till the concrete reaches its tensile strength, bending due to the stresses in the extreme fibre gets increased and due to that the flexural cracks initiated in constant moment region. The next zone indicates an incline change suddenly in the load deflection curve due to the stiffness lessening. Flexural cracks were observed in all the beam specimens. The flexural cracks were generally in the constant moment region. The decline in crack width was $27.86 \%$ at the stage of ultimate load for concrete beam strengthened using 70\%Glass + 30\%BasaltHyFRP laminate when compared to that of reference beam. Flexure mode of failure was observed in all test beams.

\section{CONCLUSIONS}

On the whole the estimation of beam test results pointed out that the HyFRP strengthened beams with 70\%Glass + $30 \%$ Basalt HyFRP laminate exhibit an escalation of $68.97 \%$ in load carrying capacity with respect to the reference test beam specimen. All the beams exhibit Flexural cracks. The percentage decrease in crack width was $27.86 \%$ at the stage of ultimate load in $70 \%$ Glass + 30\%Basalt HyFRP laminated beam when compared to that of reference beam. All the test beams be evidence for Flexure mode of failure.

\section{REFERENCES}

1. ACI, 440.2R, (2002), Guide for the Design and Construction of Externally Bonded FRP Systems for strengthening Concrete Structures, American Concrete Institute, Detroit, Michigan, USA, 1-45.

2. Attari, N., Amziane, S., \&Chemrouk, M. (2012). Flexural strengthening of concrete beams using CFRP, GFRP and hybrid FRP sheets. Construction and Building Materials, 37, 746-757.

3. Kim, H. S., \& Shin, Y. S. (2011). Flexural behavior of reinforced concrete (RC) beams retrofitted with hybrid fiber reinforced polymers (FRPs) under sustaining loads. Composite structures, 93(2), 802-811.

4. Hawileh, R. A., Rasheed, H. A., Abdalla, J. A., \& Al-Tamimi, A. K. (2014). Behavior of reinforced concrete beams strengthened with externally bonded hybrid fiber reinforced polymer systems. Materials \& Design, 53, 972-982.

5. Esmaeeli, E. (2015). Development of hybrid composite plate (HCP) for strengthening and repair of $R C$ structures (Doctoral dissertation, Universidade do Minho (Portugal)).

6. Petrucci, R., Santulli, C., Puglia, D., Nisini, E., Sarasini, F., Tirillò, J., ...\& Kenny, J. M. (2015). Impact and post-impact damage characterisation of hybrid composite laminates based on basalt fibres in combination with flax, hemp and glass fibres manufactured by vacuum infusion. Composites Part B: Engineering, 69, 507-515.

7. Sundar, N., Raghunath, P. N., \&Dhinakaran, G. (2016). Flexural behavior of RC beams with hybrid FRP strengthening. International Journal of Civil Engineering and Technology, 7(6), 2016.

\section{AUTHORS PROFILE}

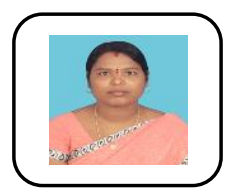

K.Pradeeba M.E., Research Scholar Department of Civil and Structural Engineering, Annamalai University, Annamalai Nagar, (Tamil Nadu), India.

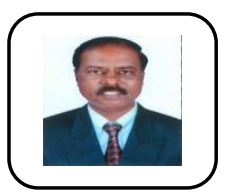

Dr. A. Rajasekaran M.E., Ph.D Professor Department of Civil and Structural Engineering, Annamalai University, Annamalai Nagar, (Tamil Nadu), India.

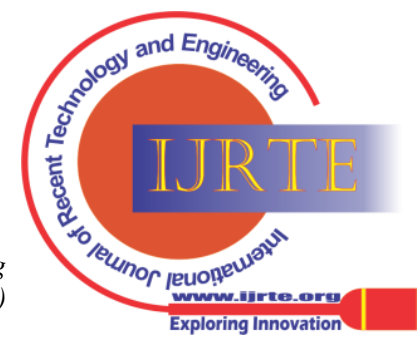

